\title{
Comparison of Student Learning Outcomes Assessment Practices Used Globally
}

\author{
By Shani D. Carter
}

\begin{abstract}
Student learning outcomes assessment examines whether programs cover the material stated in their learning goals, whether students are learning the material, and the impact on student retention, graduation, post-graduation outcomes, and institutional accreditation, with the aim of providing faculty with data that can be used to help programs evolve or improve. While there is a plethora of research regarding effective methods of assessment used in the United States, little has been written regarding cross-national comparisons of assessment methodologies. This paper examines the current state of assessment in several nations and regions, and draws parallels in practices across countries. A literature search using the term "outcomes assessment" yielded 228 articles, of which, only 35 described practices outside the United States. Generally, searches on the terms "outcomes assessment" and "global" tend to return studies of outcomes assessment of teaching about global issues as it is practiced in the United States, rather than results about outcomes assessment practices used in other countries.
\end{abstract}

Keywords: college education, global education, outcomes assessment

\section{Introduction}

Student learning outcomes assessment is conducted by colleges and universities at the undergraduate and graduate level levels for academic departments to determine whether programs cover the material stated in their learning goals, whether students are learning the material, and the impact on student retention, graduation, post-graduation outcomes, and institutional accreditation, with the aim of providing faculty with data that can be used to help programs evolve or improve (Hutchings, 2011). The assessments do not include course grades; rather, they include measures such as standardized tests or student coursework being rated outside the course by teams of faculty members.

The United States' (US) educational system is divided into three levels (a) grade school, also known as primary school (i.e., kindergarten through grade 8); (b) high school, also known as secondary school (i.e., grades 9 through 12); (c) college, also known as post-secondary school (i.e., associate's, bachelor's, master's, doctoral).

In 1988, the US federal government, via the US Department of Education (DOED), began advocating for post-secondary student learning outcomes assessment by requiring regional accreditation institutions to gather information regarding learning objectives and assessment results from colleges

${ }^{*}$ Professor, Rhode Island College, USA. 
and universities (Carter, 2009; US Department of Education, 2007). Federal law also began requiring assessment at the primary and secondary levels (i.e., No Child Left Behind Act), which also prompted post-secondary institutions to increase their outcomes assessment practices, also (Hickok, 2009; Smith, Szelest \& Downey, 2004).

The US system of outcomes assessment is flexible. The DOED standards that permit regional accreditation institutions to require post-secondary institutions to address outcomes assessment also permit institutions to set their own assessment standards and methods. The DOED standards permit universities' "developing and using institutional standards to show [their] success with respect to student achievement, which achievement may be considered as part of any accreditation re-view" (US Congress, 2009, section 602.16, [f],[2]), p. 55418).

Due to the increased federal assessment requirements in the United States, there is an increasing amount of research regarding effective methods of postsecondary outcomes assessment in the United States, but little has been written regarding cross-national comparisons of assessment methodologies. This paper examines the current state of assessment in several nations and regions, and evaluates which practices are effective for use in various countries. Countries and regions examined include: Africa, Australia; New Zealand; Canada; the United Kingdom; Asia; Europe; and the Middle East.

\section{Outcomes Assessment Methods}

Outcomes assessment can measure formative outcomes (i.e., during program) or summative outcomes (i.e., end of program), (University of the Sciences, 2011). Formative assessment measures specific knowledge, skills, abilities, and attitudes at regular intervals while students are enrolled in programs. Summative assessment measures students' entire educational experiences in a program, usually at the end of the program. Assessment instruments can be direct (e.g., tests) or indirect (e.g., employment; licensure exam; or dissertation defense) (Carter 2001; University of the Sciences, 2011).

\section{Methods}

Two literature searches were conducted to locate articles on outcomes assessment methods that are used outside the United States. First, on February 15, 2013, a search was conducted via the database Academic Search Complete (EBSCOhost) using the search term "outcomes assessment" and of 13 peerreviewed journals that focus on higher education or institutional research. The search was repeated on October 3, 2014. The 13 journals were chosen because during the initial search, these 13 journals produced assessment articles.

The titles and abstracts of the articles were reviewed to determine whether 
the articles examined outcomes assessment practices outside the United States. In cases where it was unclear, the author affiliation was examined, and if the authors were located outside of the United States, it was assumed they were discussing assessment in their home countries.

\section{Results}

\section{Number of Articles by Journal and Region}

Using the search term "outcomes assessment" yielded 228 articles, only 35 of which described practices outside the United States. Six of the 13 journals contained no articles on global assessment, while one journal contained 14 articles.

Table 1. Articles on Global Assessment in 2013 and 2014

\begin{tabular}{|c|c|c|c|c|c|c|}
\hline \multirow{3}{*}{ Journal } & \multicolumn{3}{|c|}{ To Feb. 2013} & \multicolumn{3}{|c|}{ Feb. 2013 to Oct. 2014} \\
\hline & \multirow{2}{*}{$\begin{array}{c}\text { Assess- } \\
\text { ment } \\
\text { topics }\end{array}$} & \multicolumn{2}{|c|}{$\begin{array}{c}\text { Global } \\
\text { assess }\end{array}$} & \multirow{2}{*}{$\begin{array}{c}\text { Assess- } \\
\text { ment } \\
\text { topics }\end{array}$} & \multicolumn{2}{|c|}{$\begin{array}{c}\text { Global } \\
\text { assess }\end{array}$} \\
\hline & & $f$ & $\%$ & & $f$ & $\%$ \\
\hline $\begin{array}{l}\text { Higher Education Research \& } \\
\text { Development (Australia) }\end{array}$ & 6 & 5 & 83 & 1 & 1 & $\begin{array}{c}10 \\
0\end{array}$ \\
\hline $\begin{array}{l}\text { Journal of Higher Education Policy } \\
\text { \& Management (Australia) }\end{array}$ & 2 & 1 & 50 & 4 & 4 & $\begin{array}{c}10 \\
0\end{array}$ \\
\hline $\begin{array}{l}\text { Higher Education Management \& } \\
\text { Policy (ended publication in 2012) }\end{array}$ & 4 & 3 & 75 & 0 & 0 & 0 \\
\hline Quality in Higher Education & 3 & 0 & 0 & 4 & 3 & 75 \\
\hline $\begin{array}{l}\text { Assessment \& Evaluation in } \\
\text { Higher Education (UK) }\end{array}$ & 34 & 7 & 21 & 8 & 7 & 88 \\
\hline Higher Education & 6 & 1 & 17 & 0 & 0 & 0 \\
\hline Assessment Update & 95 & 3 & 3 & 8 & 0 & 0 \\
\hline Academic Leader & 10 & 0 & 0 & 2 & 0 & 0 \\
\hline Journal of Higher Education & 5 & 0 & 0 & 0 & 0 & 0 \\
\hline $\begin{array}{l}\text { New Directions for Higher } \\
\text { Education }\end{array}$ & 7 & 0 & 0 & 3 & 0 & 0 \\
\hline $\begin{array}{l}\text { New Directions for Institutional } \\
\text { Research }\end{array}$ & 11 & 0 & 0 & 0 & 0 & 0 \\
\hline Public Relations Review & 5 & 0 & 0 & 0 & 0 & 0 \\
\hline Research in Higher Education & 10 & 0 & 0 & 0 & 0 & 0 \\
\hline Total & 198 & 20 & 10 & 30 & 15 & 50 \\
\hline
\end{tabular}

Sources: Author's estimations.

Table 1 contains data on the number and percent of articles on global assessment that were located. In 2013, 198 articles discussed outcomes assessment and 10\% (20) of these articles discussed global assessment. Of articles published between February 2013 and October 2014, 30 articles discussed outcomes assessment and 50\% (15) of these articles discussed global 
assessment. Table 1 indicates there has been a significant increase in research on global assessment.

Table 2 contains data on the number and percent of articles on global assessment that were located during both searches. By October 2014, a total of 10,750 articles were published in the 13 higher education or institutional research journals. Of these, $2.1 \%$ (228) articles discussed assessment, and of those, $15 \%$ (35) discussed global assessment. In summary, it is clear that outcomes assessment is rarely the subject of research in the higher education literature, and that outcomes assessment practices outside the US also are rarely discussed.

Table 2. Articles on Global Assessment in 2014 (by October)

\begin{tabular}{|l|c|c|c|c|c|}
\hline \multirow{2}{*}{ Journal } & \multicolumn{4}{|c|}{ Papers published } \\
\cline { 2 - 6 } & \multirow{2}{*}{$\begin{array}{c}\text { All } \\
\text { topics }\end{array}$} & \multicolumn{2}{|c|}{$\begin{array}{c}\text { Assessment } \\
\text { topics }\end{array}$} & \multicolumn{2}{c|}{$\begin{array}{c}\text { Global } \\
\text { assessment } \\
\text { topics }\end{array}$} \\
\cline { 2 - 6 } & $f$ & $f$ & $\%$ & $f$ & $\%$ \\
\hline $\begin{array}{l}\text { Higher Education Research \& } \\
\text { Development (Australia) }\end{array}$ & 704 & 7 & 1.0 & 6 & 85.7 \\
\hline $\begin{array}{l}\text { Journal of Higher Education Policy } \\
\text { \& Management (Australia) }\end{array}$ & 593 & 6 & 1.0 & 5 & 83.3 \\
\hline $\begin{array}{l}\text { Higher Education Management \& } \\
\text { Policy (ended publication in 2012) }\end{array}$ & 223 & 4 & 1.8 & 3 & 75.0 \\
\hline Quality in Higher Education & 404 & 7 & 1.7 & 3 & 42.9 \\
\hline $\begin{array}{l}\text { Assessment \& Evaluation in Higher } \\
\text { Education (UK) }\end{array}$ & 1,152 & 42 & 3.6 & 14 & 33.3 \\
\hline Higher Education & 1,362 & 6 & 0.4 & 1 & 16.7 \\
\hline Assessment Update & 699 & 103 & 14.7 & 3 & 2.9 \\
\hline Academic Leader & 704 & 12 & 1.7 & 0 & 0 \\
\hline Journal of Higher Education & 1,213 & 5 & 0.4 & 0 & 0 \\
\hline $\begin{array}{l}\text { New Directions for Higher } \\
\text { Education }\end{array}$ & 825 & 10 & 1.2 & 0 & 0 \\
\hline $\begin{array}{l}\text { New Directions for Institutional } \\
\text { Research }\end{array}$ & 695 & 11 & 1.6 & 0 & 0 \\
\hline Public Relations Review & 1,405 & 5 & 0.4 & 0 & 0 \\
\hline Research in Higher Education & 771 & 10 & 1.3 & 0 & 0 \\
\hline Total & 10,750 & 228 & 2.1 & 35 & 15 \\
\hline Sourcs: Aun & & & &
\end{tabular}

Sources: Author's estimations.

Table 3 contains data on the number and percent of articles by the country that was the focus of the article. Of the 35 articles, more than half $(51.4 \%)$ focused on Australia and New Zealand because two of the journals are based in Australia. In second place, the United Kingdom was the focus of $11.4 \%$ of the articles. All other countries and regions were the focus of less than $10 \%$ of the articles each. 
Table 3. Countries and Regions that are Discussed in Articles

\begin{tabular}{|l|c|c|c|c|}
\hline Country or Region & $\mathbf{2 0 1 3}$ & $\mathbf{2 0 1 4}$ & Total & \% \\
\hline Africa & 0 & 1 & 1 & 2.9 \\
\hline Asia & 3 & 0 & 3 & 8.6 \\
\hline Australia \& New Zealand & 8 & 10 & 18 & 51.4 \\
\hline Canada & 1 & 1 & 2 & 5.7 \\
\hline Europe & 2 & 1 & 3 & 8.6 \\
\hline Middle East & 2 & 0 & 2 & 5.7 \\
\hline United Kingdom & 3 & 1 & 4 & 11.4 \\
\hline South America & 0 & 1 & 1 & 2.9 \\
\hline Global-other & 1 & 0 & 1 & 2.9 \\
\hline Total & 20 & 15 & 35 & 100.0 \\
\hline
\end{tabular}

Sources: Author's estimations.

\section{Africa}

In Tanzania, which gained independence in 1961, colleges and universities slowly began to gain some decision-making autonomy from the federal government during 1995-2005, and received more autonomy by passage of the 2005 Universities Act. Currently, there are "11 public and 17 private universities, 4 public and 15 private university colleges, and another 14 centres or institutes," that are registered with the National Council for Technical Education (NACTE), (Ngirwa, Euwema, Babyegeya \& Stouten, 2014, p. 133). Researchers are examining best practices for shared governance and highquality outcomes assessment.

\section{Asia}

In Japan, in 2008, there were 765 universities which enrolled nearly 3 million students (Kushimoto, 2010). Approximately $70 \%$ of the universities and students were in the private sector. Reform of the Japanese higher education field began in the 1990's to increase focus on assessment and evaluation and, in 1999, universities were required to conduct self-review and to publish the results. Although $98 \%$ of colleges conducted self-review, only some colleges included outcomes assessment in the self-review. The goal of self-review and assessment was primarily to satisfy mandates as opposed to promoting improvement in the universities, but there was an increasing shift toward program improvement.

In Japan, methods used to conduct outcomes assessment were direct and indirect. Because, historically, self-review was focused on mandates rather than curriculum improvement, most of the assessment methods that were used were indirect, and assessment results were not routinely used to improve programs. Direct methods and approximate percent of universities included: subjectmatter tests, 35\%; senior research, 60\%; portfolio, 15\%; and national examinations, 50\%. Indirect methods and approximate percent of universities included: destinations of graduates, $90 \%$; grades, $70 \%$; student survey, $70 \%$; faculty survey, 50\%; graduate survey, 30\%; and employer survey, $20 \%$. 
Hong Kong was ruled as a British colony until 1997, and therefore is not representative of the reminder of the People's Republic of China. Outcomes assessment was conducted in Hong Kong since at least 1993, following the City Polytechnic of Hong Kong (CPHK) publishing assessment guidelines (Imrie, 1995). The dual goals of assessment were accountability and program improvement (Kennedy, 2011).

The 1993 publication of the Hong Kong guidelines prompted faculty members to discuss of taxonomies of levels of student learning (e.g., Bloom: knowledge, comprehension, etc.; Steinaker and Bell: exposure, participation, etc.), but the taxonomies were not subsequently used in designing curriculum or designing assessment programs. Between 1993 and 2005, the universities continued to look outside China for guidance on outcomes assessment, and discussion and planning were led by experts from outside China (Kennedy, 2011).

By 2005, Hong Kong outcomes assessment planning was led by local faculty, some universities were more accepting of outcomes assessment as a means to improve academic programs and to ensure quality, and they began to move away from measuring only inputs (e.g., faculty credentials), (Kennedy, 2011). Assessment began to focus on student and faculty behaviors - what students and faculty need to do to ensure students learn the material. Course activities were aligned with outcomes, and course outcomes were combined to create higher level, comprehensive outcomes that enable graduates to have successful employment outcomes.

\section{Australia and New Zealand}

In Australia, a new national organization, the Tertiary Education Quality and Standards Agency (TEQSA), assesses higher education providers, including teaching and learning standards (King \& James, 2014). There is movement away from using only indirect measures (e.g., exit interviews) and toward using direct measures (e.g., tests, rubrics) for assessment (French, et al., 2014), because there are differences in outcomes assessment results when using indirect student selfreports versus using direct knowledge measures (Jackson, 2014).

Assessment should be conducted at three levels (a) program, via curriculum mapping; (b) course, via student written work; (c) task (Hughes, 2013). The value added by higher education was assessed via direct and indirect methods, including (a) a nationally-standardized assessment of general skills (e.g., written communication) for first and fourth-year students; (b) student engagement (i.e., the Australasian Survey of Student EngagementAUSSE); (c) employer evaluations of alumni skills (i.e., the Employer Questionnaire-EQ), (Coates, 2009).

For course assessment, using student written commentaries of their cognitive maps was a reliable and useful method of outcomes assessment (Jones, van Kessel, Swisher, Beckstead, \& Edwards, 2014). Large class sizes negatively impacted higher-order learning (e.g., negotiation) and also led to assessment being conducted via exams rather than via student research (McDonald, 2013). 
For assessment of assignments, many methods were used. First, using student learning, student feedback, course grades, and course retention showed learning-to-learn activities improved student outcomes (Zeegers \& Martin, 2010). Second, using student peer review positively impacted student learning outcomes because the peer review provided students with a greater amount of feedback on their performance than they would receive from the professor alone, and enabled students to learn performance standards, and to learn from other students (Mulder, Baik, Naylor, \& Pearce, 2014). Third, providing frequent, detailed assessment from faculty using scaffolded assignments improved learning outcomes on subsequent assignments (Vardi, 2013). Fourth, interviews and questionnaires using Likert-scales, and faculty ratings via rubrics, were used to measure student skills, to provide feedback to faculty to improve their teaching (Willison, 2012).

For assessment of student perceptions, using online-based assessments (rather than paper-based) to measure teamwork and research skills, and using a grade-based scale (rather than a Likert scale) resulted in higher student satisfaction with the rating process and more accurate scores $(\mathrm{Wu}$, Chanda \& Willison, 2014). Second, using Likert-type scales and open ended responses to measure student perceptions of assessment showed students' primary concerns were lack of agreement between students and faculty regarding student level of performance and students' not receiving feedback on their performance (Winning, Lim \& Townsend, 2005).

For employability (e.g., critical thinking, problem-solving) and employment-related performance, assessment is conducted in various ways. Employability outcomes were based on curriculum maps and professional accreditation competencies, when applicable (Oliver, 2013). The WatsonGlaser Critical Thinking Appraisal was used to measure critical thinking, and showed that students had low motivation to perform well if they believed the test results would not impact their course grades (Macpherson \& Owen, 2010).

For experiential placements (e.g., internships) assessment often consisted of student evaluations, but rarely measured learning outcomes, such as professional competencies (Owen \& Stupans, 2009). Employment-related outcomes were measured via: portfolios using teacher, self, and peer review; self-report, alumni, employer surveys (Oliver, 2013); and the Work Experience Questionnaire (WEQ), a survey of students to assess the quality of job-based learning (e.g., service learning, internships, placements), (Freestone, Williams, Thompson \& Trembath, 2007).

In New Zealand, when assessment was beginning around 1990, some universities provided developmental programs for administrators and department heads to deliver knowledge of the outcomes assessment process, including developing learning goals, measurement methods, and methods to provide feedback to faculty to have them learn to improve curriculum (Meade, Morgran \& Heath, 1999). 


\section{Canada}

In Canada, the focus was on creating learning goals and providing faculty development, rather than on measuring learning outcomes. For example, universities created centers to provide faculty development on how students learn and on methods of pedagogy to improve student learning outcomes (Kanuka, 2010). There also was an increase in the number of international students to help meet the outcome of "helping (Canadian) students to develop a broader world view and better preparing (Canadian) students to interact in an increasingly globalized economy" (Skinkle \& Embleton, 2014, p. 45). Assessment of international-student-related issues measured inputs (e.g., type of curriculum offered) rather than learning outcomes.

\section{Europe}

In Europe, outcomes assessment was often referred to as "quality" or "quality assurance" (Banta, 2009). They advocated giving academic departments freedom to determine the content and methods of assessment and providing faculty development to improve student learning. There also was considerable debate about designing learning outcomes (e.g., should outcomes be standardized across universities and countries; and should outcomes be created at all), (Banta, 2009).

In the Netherlands, researchers examined the relationship between achievement of learning outcomes and progress toward degree (i.e., college credits obtained), (Kamphorst, Hofman, Jansen \& Terlouw, 2013). There was a weak relationship between perceived competence and credits obtained, so colleges should ensure there is a strong link between learning goals and progress toward degree to avoid students' graduating without mastering important knowledge.

In Sweden, each course was required to undergo a multifaceted "course analysis" annually, including: number of students registered and completion rate; student opinions of the course; faculty analysis; and statements of changes in the course due to course analysis. The student opinions were useful for examining teaching, but were inappropriate to use for course development or outcomes assessment (Edström, 2008).

\section{Middle East}

In the United Arab Emirates (UAE), assessment has been conducted since 1999, and began with creating a 5-year plan for assessment of program and general education learning outcomes (Dodeen, 2003). For faculty development in regard to assessment, universities offered workshops, formed committees, distributed assessment literature, publicized assessment results on the internet, and hired consultants to meet with faculty, staff, and students. Assessment measures included student surveys, standardized tests, and student interviews. Faculty and administrators believed assessment activities should be tied to 
course grades and graduation requirements to ensure students were motivated to perform well (Dodeen, 2003).

Many faculty and administrators were educated outside the Middle East, and many were natives of Europe and the United States, who bought innovative ideas to the UAE (Banta, 2003). The UAE faculty members attended assessment conferences worldwide, and the UAE and non-UAE faculty and administrators collaborated to design learning goals and assessment methodologies, and to benchmark their work against the work of non-UAE universities (Banta, 2003; Dodeen, 2003). They used assessment results to seek accreditation from western institutions such as American Assembly of Collegiate Schools of Business (AACSB) and National Council for Accreditation of Teacher Education (NCATE).

\section{The United Kingdom}

In Wales, assessment was conducted on student written assignments, and was used to close-the-loop by distributing grading criteria and results to students and having them use the results to improve their learning (Case, 2007). Multiple raters assessed student work. Sharing learning outcomes and grading criteria with students positively impacted their performance.

In Great Britain and Australia, researchers surveyed students using 42 questions and 9-point scales to measure course quality and the alignment of teaching and learning activities and assessments with learning outcomes in workintegrated learning (WIL; e.g., internships, practica, supervised practice, simulations), (Smith, 2012). Also, in Great Britain, when comparing learning outcomes for English as a Second Language (ESL) students to learning outcomes for English as a Primary Language (EPL) students in an MBA program, it was found that weaker English skills have a stronger negative impact on timed test scores than on untimed assignment scores, and that untimed assignments were a more valid measure of student learning (Smith, 2011). Last, in the United Kingdom, researchers examined the validity of a measure of institutional quality of the United Kingdom's National Student Survey (NSS) which obtains student feedback on student engagement (Williams, 2014).

\section{South America}

The Brazilian higher educational system is predominately closed to researchers from other countries, so information on its assessment programs is lacking. Brazilian universities and academic programs have "taken what [they] find valuable from the world-class movement, so to build universities for and by Brazilians, without a deliberate attempt to reach beyond [their] borders" (Alperin, 2013, p. 160-161). In practice: more than $90 \%$ of faculty and students are Brazilian; most coauthors of journal articles are Brazilian; Brazil has about 30 journals, and most of these are indexed only in a Brazilian search engine (i.e., Scientific Electronic Library Online, SciELO), not in US based search engines (e.g., Web of Science). 


\section{Other Global Areas}

The Organisation for Economic Cooperation and Development (OECD) developed an "international assessment of bachelor degree students' learning outcomes" named the Assessment of Higher Education Learning Outcomes (AHELO), (Coates \& Richardson, 2011, p. 53). The AHELO measured knowledge in: general education (e.g., teamwork; oral and written communication; creativity; analytical; and leadership); economics; and engineering. The AHELO was designed to produce assessment results that are generalizable across institutions and countries, in contrast to other assessment methods that were institution-based. Thus, the AHELO was a summative assessment (to rank institutions), and was not designed to provide formative-level feedback to faculty that could be used in curriculum design. The OECD used subject matter experts to design the learning outcomes and assessment instruments. The instruments were validated in terms of content, language, and culture, and were pilot tested.

\section{Conclusions}

The English-language literature on outcomes assessment methods is sparse, consisting of 228 of 10,750 papers $(2.1 \%)$ in 13 higher education journals. Of these 228 assessment papers, only 35 (15\%) discussed outcomes assessment methods that are used outside the United States, with half of the papers focusing on Australia.

Nevertheless, the literature indicates outcomes assessment is practiced worldwide. In some countries, assessment is top-down, being legally mandated, mandated by accreditation, or required by college administrators. Universities in countries that have always had democratic governments and academic freedom of faculty have conducted assessment for many decades and have assessment processes that are more well-developed than universities in countries that became democratic in the last 50 years or that do not have democratic governments.

In all countries, faculty are usually permitted to have input into the content of learning goals and creation of curriculum maps, and faculty show more support for assessment when they are given input into the assessment decisionmaking process. Learning goals range in specificity of content from general (e.g., written communication) to program specific (e.g., engineering).

Faculty also usually have input into the design of assessment methods and processes. Assessment methods include multiple-choice tests, essays, portfolios, surveys, and interviews, while raters include faculty, students, alumni, and employers. Assessment is conducted at the undergraduate and graduate level.

Assessment results are usually used to close-the-loop, i.e., change curriculum and pedagogy in response to assessment results. Generally, if assessment is conducted with faculty input at each step of the process, and if faculty attempt to close-the-loop, then student learning outcomes improve. There is no single best method of outcomes assessment; rather assessment should be tailored to institutional, programmatic, and student characteristics. 


\section{Acknowledgements}

My thanks to President Nancy Carrioulo and Vice President for Academic Affairs, Ron Pitt, of Rhode Island College, who provided resources that enabled me to conduct this study.

\section{References}

Alperin, J. P. (2013). Brazil's exception to the world-class university movement. Quality in Higher Education, 19(2), 158-172. http://dx.doi.org/10.1080/13538 322.2013.802573

Banta, T. W. (2003). Assessment at the United Arab Emirates University. Assessment Update, 15(1). 3-11.

Banta, T. W. (2009). Sour Notes from Europe. Assessment Update, 21(6). 3-7.

Carter, S. D. (2001). Assessment. In J. Michee (Ed.), Reader's Guide to the Social Sciences, 84-85. London: Fitzroy Dearborn.

Carter, S. D. (2009). A ten step process for creating outcomes assessment measures for an undergraduate management program: A faculty driven process. Professional File 113, 1-15. Association for Institutional Research.

Case, S. (2007). Reconfiguring and realigning the assessment feedback processes for an undergraduate criminology degree. Assessment \& Evaluation in Higher Education, 32(3), 285-299. http://dx.doi.org/10.1080/026029306008 96548.

Coates, H. (2009). What's the difference? A model for measuring the value added by higher education in Australia. Higher Education Management and Policy, 21(1), 77-95.

Coates, H. \& Richardson, S. (2011). An international assessment of bachelor degree graduates' learning outcomes. Higher Education Management and Policy, 23(3), 51-69.

Dodeen, H. (2003). Assessment of educational outcomes at the United Arab Emirates University: Issues and solutions. Assessment Update, 15(1), 4-5.

Edström, K. (2008). Doing course evaluation as if learning matters most. Higher Education Research \& Development, 27(2), 95-106. http://dx.doi.org/10.1080/ 07294360701805234

Freestone, R., Williams, P., Thompson, S., \& Trembath, K. (2007). A quantitative approach to assessment of work-based learning outcomes: an urban planning application. Higher Education Research \& Development, 26(4), 347-361. http://dx.doi.org/10.1080/07294360701658575.

French, E., Summers, J., Kinash, S., Lawson, R., Taylor, T., Herbert, J., Fallshaw, E., \& Hall, C. (2014). The practice of quality in assuring learning in higher education. Quality in Higher Education, 20(1), 24-43. http://dx.doi.org/10.1080/ 13538322.2014.889432.

Hickok, E. (2009). No undergrad left behind. New York Times. Retrieved from http://nyti.ms/1bzqDpt.

Hughes, C. (2013). A case study of assessment of graduate learning outcomes at the programme, course and task level. Assessment \& Evaluation in Higher Education, 38(4), 492-506. http://dx.doi.org/10.1080/02602938.2012.658020. 
Hutchings, P. (2011). What New Faculty Need To Know About Assessment. Champaign, IL: National Institute for Learning Outcomes Assessment. Retrieved from http://bit.ly/1DSAVaE.

Imrie, B. W. (1995). Assessment for learning: Quality and taxonomies. Assessment \& Evaluation in Higher Education, 20(2), 175-190.

Jackson, D. (2014). Self-assessment of employability skill outcomes among undergraduates and alignment with academic ratings. Assessment \& Evaluation in Higher Education, 39(1), 53-72. http://dx.doi.org/10.1080/02602938. 2013.792107.

Jones, M., van Kessel, G., Swisher, L., Beckstead, J., \& Edwards, I. (2014). Cognitive maps and the structure of observed learning outcome assessment of physiotherapy students' ethical reasoning knowledge. Assessment \& Evaluation in Higher Education, 39(1), 1-20. http://dx.doi.org/10.1080/02602938.2013. 772951.

Kennedy, K. J. (2011). Conceptualising quality improvement in higher education: policy, theory and practice for outcomes based learning in Hong Kong. Journal of Higher Education Policy \& Management. 33(3), 205-218. http://dx.doi.org/10.1080/1360080X.2011.564995.

Kamphorst, J. C., Hofman, W. H. A., Jansen, E. P. W. A., \& Terlouw, C. (2013). The relationship between perceived competence and earned credits in competencebased higher education. Assessment \& Evaluation in Higher Education, 38(6), 646-661.

Kanuka, H. (2010). Characteristics of effective and sustainable teaching development programmes for quality teaching in higher education. Higher Education Management and Policy, 22(2), 69-81.

King, C. \& James, R. (2014). Increasing participation and attainment in higher education in Australia: The early effects of a "demand-driven" system. Higher Education Management and Policy, 24(3), 145-160.

Kushimoto, T. (2010). Outcomes assessment and its role in self-reviews of undergraduate education: in the context of Japanese higher education reforms since the 1990s. Higher Education, 59(5), 589-598. http://dx.doi.org/10. 1007/s10734-009-9266-1.

Macpherson, K. \& Owen, C. (2010). Assessment of critical thinking ability in medical students. Assessment \& Evaluation in Higher Education, 35(1), 45-58. http://dx.doi.org/ 10.1080/02602930802475471.

Meade, P., Morgran, M. \& Heath, C. (1999). Equipping leaders to capitalize on the outcomes of quality assessment in higher education. Assessment \& Evaluation in Higher Education, 24(2), 147-156.

McDonald, G. (2013). Does size matter? The impact of student-staff ratios. Journal of Higher Education Policy and Management, 35(6), 652-667. http://dx.doi.org/ 10.1080/1360080X.2013.844668.

Mulder, R., Baik, C., Naylor, R. \& Pearce, J. (2014). How does student peer review influence perceptions, engagement and academic outcomes? A case study. Assessment \& Evaluation in Higher Education, 39(6), 657-677. http://dx.doi. org/10.1080/02602938.2013.860421.

Ngirwa, C. C., Euwema, M., Babyegeya, E., \& Stouten, J. (2014). Managing change in higher education institutions in Tanzania: A historical perspective. Higher Education Management and Policy, 24(3), 127-144.

Oliver, B. (2013). Graduate attributes as a focus for institution-wide curriculum renewal: innovations and challenges. Higher Education Research \& Development, 32(3), 450-463. http://dx.doi.org/10.1080/07294360.2012.682052 
Owen, S. \& Stupans, I. (2009). Australian pharmacy programme experiential placements: comprehensive planning for assessment and evaluation. Assessment \& Evaluation in Higher Education, 34(5), 579-594. http://dx.doi.org/10. 1080/02602930802255154.

Skinkle, R. \& Embleton, S. (2014). Comparing international student and institutional objectives at Canadian colleges and universities: Implications for institutional strategy. Higher Education Management and Policy 24(3), 37-55.

Smith, C. (2011). Examinations and the ESL student - more evidence of particular disadvantages. Assessment \& Evaluation in Higher Education, 36(1), 13-25. http://dx.doi.org/10.1080/02602930903173959.

Smith, C. (2012). Evaluating the quality of work-integrated learning curricula: a comprehensive framework. Higher Education Research \& Development, 31(2), 247-262. http://dx.doi.org/10.1080/07294360.2011.558072.

Smith, J. S., Szelest, B. P., \& Downey, J. P. (2004). Implementing outcomes assessment in an academic affairs support unit. Research in Higher Education 45(4), 405-427.

University of the Sciences. (2011). Institutional Assessment. Philadelphia, PA: University of the Sciences. Retrieved from http://bit.ly/1JNMEvQ.

US Congress. (2009). Federal Register, Institutional Eligibility Under the Higher Education Act of 1965, as Amended, and the Secretary's Recognition of Accrediting Agencies; Final Rule. Washington, D.C. Retrieved from http://1.usa.gov/1do5M9z

US Department of Education. (2007). Accreditation in the United States. Retrieved from http://1.usa.gov/1OyZy7J.

Vardi, I. (2013). Effectively feeding forward from one written assessment task to the next. Assessment \& Evaluation in Higher Education, 38(5), 599-610. http://dx.doi.org/10.1080/02602938.2012.670197.

Williams, J. (2014). Editorial. Quality in Higher Education, 20(2), 127-128. http://dx.doi.org/ 10.1080/13538322.2014.940762.

Willison, J. W. (2012). When academics integrate research skill development in the curriculum. Higher Education Research \& Development, 31(6), 905-919. http://dx.doi.org/10.1080/07294360.2012.658760.

Winning, T., Lim, E. \& Townsend, G. (2005). Student experiences of assessment in two problem-based dental curricula: Adelaide and Dublin. Assessment \& Evaluation in Higher Education, 30(5), 489-505. http://dx.doi.org/ 10.1080/02602930500187014.

Wu, C., Chanda, E., \& Willison, J. (2014). Implementation and outcomes of online self and peer assessment on group based honours research projects. Assessment \& Evaluation in Higher Education, 39(1), 21-37. DOI: 10.1080/02602938. 2013.779634.

Zeegers, P. \& Martin, L. (2010). A learning-to-learn program in a first-year chemistry class. Higher Education Research \& Development, 20(1), 35-52. DOI: 10.1080/07924360120043630. 
